\title{
A rare cause of acute cholecystitis: ascariasis
}

\section{Nadir görülen bir akut kolesistit nedeni: askariyazis}

\author{
Arzu Boztaş ${ }^{1}$ Hakan Buluş², Alper Yavuz ${ }^{3}$, Ahmet Murat Koyuncu ${ }^{4}$ \\ ${ }^{1}$ Çermik Devlet Hastanesi Genel Cerrahi Kliniği, Diyarbakır, Türkiye \\ ${ }^{2}$ Keçiören Eğitim ve Araştırma Hastanesi Genel Cerrahi Kliniği, Ankara, Türkiye \\ ${ }^{3}$ Afyonkarahisar Devlet Hastanesi Genel Cerrahi Kliniği, Afyon, Türkiye
}

Received: 16.11 .2017

Accepted: 27.12.2017

Doi:10.21601/ortadogutipdergisi.354521

\begin{abstract}
Ascariasis is common helmintic infestation in adult man. It is rare in gallbladder (GB) despite it is common in intestinal and biliary tract. Ascariasis in the GB is an entity that generally presented with acalculous cholecystitis symptoms (low grade fever, right upper abdominal colic and tenderness). Ultrasonographic evaluation showes that thick GB wall and intraluminal tartarus. We present a case, which is 37 year old man underwent a laparoscopic cholecystectomy for a polyp in the GB. Histopathological examination showed us an ascariasis in the GB.
\end{abstract}

Keywords: Ascariasis, cholecystitis, cholecystectomy

\section{Öz}

Askariyazis erkek erişkinlerde yaygın görülen helmitik bir enfestasyondur. İntestinal ve safra kanalı askariyazisi yaygın olarak görülmesine rağmen, safra kesesi içerisinde çok nadir görülmektedir. Safra kesesi askariyazisi genellikle akalkülöz kolesistit (subfebril ateş, sağ üst kadranda kolik tarzında ağrı, hassasiyet) bulguları ile kendini belli eden bir antitedir. Ultrasonografik değerlendirmede safra kesesi duvarında hafif kalınlaşma ve lümen içerisinde tortiyöz kalıntı şeklinde görüntülenmektedir. Biz safra kesesinde polip ya da çamur nedeniyle akut kolesistit kliniği ile laparaskopik kolesistektomi uygulanan, daha sonra histopatolojik değerlendirmede safra kesesi askariyazisine rastlanan 37 yaşında erkek bir olguyu sunduk.

Anahtar Kelimeler: Askariyazis, kolesistit, kolesistektomi

\section{Introduction}

Ascaris lumbricoides infestation is the most common helminthic infection to infest adult man. Ascariasis is a common intestinal parasitic disease in many developing countries and is a common cause of biliary and pancreatic diseases in endemic areas [1]. The presentation is usually due to massive infestations resulting in intestinal obstruction, volvulus, and intussusceptions [2]. Parasites can migrate into the biliary tract and create problems such as recurrent pyogenic cholangitis, gall stones, and pancreatitis. Gall bladder ascariasis is seen at $2.1 \%$ biliary ascariasis cases[3,4]. Acalculous cholecystitis caused by A. lumbricoides is seen in endemic areas [5].

\section{Case Report}

37-year-old man, of low socio-economic stratus, presented with history of right upper abdomen pain of 3 weeks duration. There was low-grade fever aggravation with pain. There was no history of jaundice and vomiting. Physical examination showed that tenderness in right hypochondriac region, no palpable mass, no hepatomegaly. His laboratory findings revealed hemoglobin: $13 \mathrm{~g} / \mathrm{dl}$, total count of leucocyte was 10900/dl, neutrophils: 70\%, lymphocytes: 19\%, eosinophils: $11 \%$, ESR : $11 \mathrm{~mm} / \mathrm{h}$. Liver function tests were normal, Alkaline phosphatase was 78U/L. Abdomen ultrasonography showed sludge and polyp in the 
GB. GB wall thickness was $4 \mathrm{~mm}$, common bile duct was $6 \mathrm{~mm}$. There was no stone in the GB and no dilatation of intrahepatic biliary radicals. He underwent a laparoscopic cholecystectomy. There was a dead A. lumbricoides measuring $8 \mathrm{~cm}$ in length in GB (Figure 1). Histopathologic findings revealed features of eosinophilic cholecystitis. He had not have a complication at the postoperative period and discharged on the 3. post operative day with antihelmenthic medications that was recommendations by infectious disease clinic.

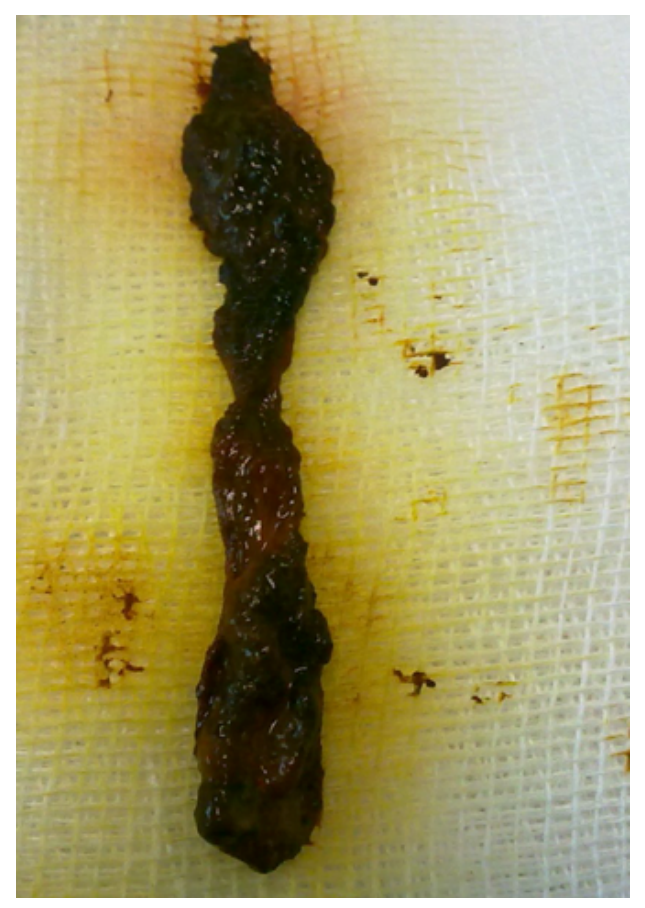

Figure 1. A dead ascaris lumbricoides removed from the GB.

\section{Discussion}

Biliary ascariasis is a known cause of biliary and pancreatic system diseases in endemic areas [1]. Although intestinal and bile duct ascariasis is common, A. lumbricoides in the GB is uncommon, even in endemic areas [5]. It is endemic in third world countrieswhere poor health standards, low socioeconomic status and geoclimatic conditions influence the parasite prevalence in these parts of the world [6].

Warm climate and humid soil conditions in the tropical and subtropical countries provide ideal conditions for this infection to flourish [5]. In uncomplicated biliary ascariasis, the clinical picture merges with that of acute acalculus cholecystitis with low grade fever, upper abdominal colic, tenderness, muscle guarding in right upper quadrant with a gall bladder mass. It maybe complicated by acute cholan- gitis with fever, right hypochondriac pain, jaundice, tender hepatomegaly, raised bilirubin, alkaline phosphatase, and transaminases. Cholangitis may be suppurative and patient may present with shock [7].

Biliary ascariasis can be diagnosed by hepatobiliary ultrasonography. Ultrasonography is a highly sensitive and specific method of detection of worms in the biliary tree. It maybe repeated frequently to monitor the movement of worms in the duct [8].

ERCP is a good modality but it is invasive and has certain well known hazarads [1]. MRCP has established a well accepted place for itself in the evaluation of pancreatobiliary system in general [9].

Majority of patients with hepatobiliary and pancreatic ascariasis respond to medical treatment [10]. Worms in the biliary tract are not killed by standard antihelminthic drugs as these are excreted in less than $1 \%$ in bile and have, thus, no effect [11]. The established treatments for biliary ascariasis are antihelminthic drug therapy, endoscopic extraction, and surgical extraction [12].

\section{Conclusion}

Ascariasis in the GB is a rare despite it is common in intestinal tract. It can diagnose preoperatively by the ultrasonography The treatment is antihelmintic drugs and cholecystectomy.

\section{Declaration of conflicting interests}

The author declared no conflicts of interest with respect to the authorship and/or publication of this article.

\section{References}

1. Khuroo MS, Zargar SA. Biliary ascariasis: a common cause of biliary and pancreatic disease in an endemic area. Gastroentrology 1985;88:418-23.

2. Rode H, Cullis S, Millar A, Cremin B, Cywes S. Abdominal complications of ascaris lumbricoides in children. Pediatr Surg Int 1990;5:397-401.

3. Javid G, Wani N, Gulzar GM, Javid O, Khan B, Shah A. Gallbladder ascariasis: presentation and management. Br J Surg 1999;86:1526-7.

4. Almiş H, Çatal F, Karadağ A. Nadir bir kronik karın ağrısı nedeni: Safra kesesi ascariyazisi. The Journal of Pediatric Research 2014;1:226-8.

5. Khuroo MS, Zargar SA, Mahajan R. Hepatobiliary and pancreatic ascariasis in India. Lancet 1990;335:1503-6. 
6. Gabaldon A, Mofidi C, Morishita K, et al. Control of Ascariasis. Report of WHO expert Committee. World Health Organ. Tech Report Ser 1967;379:6-7.

7. Thomas PG, Ravindra KV. Amoebiasis and biliary infection. In: Blumgart LH. Fong Y, editors. Surgery of the liver and biliary tract. 3 rd ed. New York: W.B. Saunders Imprint-Elsevier Science; 2001.p.1161-5.

8. Shah OJ, Dar MA, Wan NA, Robbani I, Zargar SA. Biliary ascariasis as a cause of post-cholecystectomy syndrome in an endemic area. Dig Surg 2004;21:108-13.

9. Ng KK, Wong HF, Kong MS, Chiu LC, Tan CF, Wan YL. Biliary ascariasis: CT, MR cholangiopancreatography, and navigator endoscopic appearance-report of a case of acute biliary obstruction. Abdom Imaging 1999;24:470-2.
10. Khuroo MS, Zargar SA Biliary ascariasis: a common cause of biliary and pancreatic disease in an endemic area. Gastroentrology $88: 418-423$.

11. Hardman JG, Limbird LE, Gilman AG Goodman and Gilman's the pharmacological basis of therapeutics, 10th edn.McGraw-Hill, New York, 2002:1122-37.

12. Yoshihara S, Toyoki Y, Takahashi O, Sasaki M. Laparoscopic treatment for biliary ascariasis. Surg Laparosc Endosc Percutan Tech 2000;10: 103-5.

Sorumlu Yazar: Arzu Boztaş, Çermik Devlet Hastanesi Genel Cerrahi Bölümü, Diyarbakır, Türkiye

E-mail: arzuboztas85@hotmail.com 